\title{
Histopathological Study of Lung, Testis, and Urinary Bladder of Mice Treated with 5-Fluorouracil
}

\author{
Njlaa Kh. Al-Jawaly \\ Department of Biology/ College of Science/ \\ University of Mosul
}

\author{
Hafidh I. Al-Sadi * \\ Department of Oral and Maxillofacial Surgery/ \\ College of Dentistry/ University of Mosul \\ *E.mail: hafidhalsadi@ yahoo.com
}

(Received 26/6/2013;Accepted 25/11/2013)

\begin{abstract}
The histopathological effects of variable intraperitoneal doses of 5-fluorouracil (5-FU) on lung, testis and the urinary bladder of mice were studied. Following administration of 5- FU according to the dosing schedule used in this study various lesions appeared in the lungs and they included emphysema and thickening of the interalveolar septa due to congestion, hemorrhage and infiltration of mononuclear cells. In the testes and the urinary bladder, edema of the testicular interstitium, degeneration of the spermatocytes, lack of spermatozoa and hyperplasia of the transitional epithelium of the urinary bladder were seen. When the dose and time of exposure were increased additional lesions appeared and they included congestion of blood vessels within the testicular interstitium and hyperplasia of the interstitial cells. Congestion of blood vessels and fibrosis were seen within the submucosa of the urinary bladder, and in the lungs, peribronchiolar lymphoid hyperplasia was evident. From the results of this study it was concluded that 5-FU in the doses used in this study was associated with histopathological lesions in the lung, testis and urinary bladder of mice.
\end{abstract}

Keywords: Histopathology, 5-fluorouracil, lung, testis, urinary bladder, mice.

\section{درلسة نسجية مرضية للرئة والخصية والمثلنة البولية الفئرل المعاملة بقار \\ 5-Fluorouracil}

\begin{abstract}
المالخص
تمت درلسة التأثيرات النسجية المرضية لجرع مختلفة بدلخل الخلب لعقار 5-Fluorouracil (5-FU) في رئة وخ صية ومثانة الفئران. بعد إعلاء 5-FU هسب جدول التجريع المتع في هذه الدرلسةظهرت الفلت مختلفة وتضمنت الفاخ الرئوي وتشخن

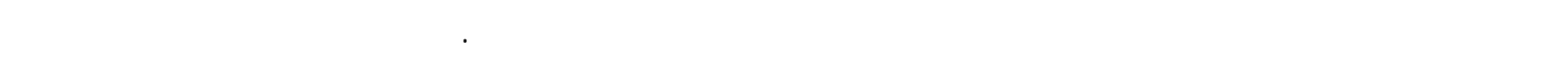

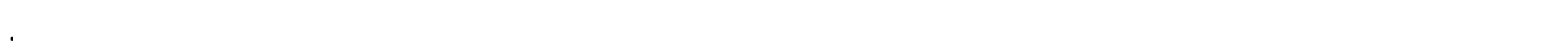
وعند زيادة جرعة العقار وفترة التعريضظهرت الفلت مضافة تضمنت لحقلن الاوعية الموية بدلخل النسج الخل ـوي الخ صصوي وفرط تنسج الخلايا الخلالية. ولوظظ وجود لحقلن الاوعية الموية والتلف في الطقة تمت المخلطية للمثانة البولية وف ـرط تن سج لمفي حول القصيبة الهوائية في الرئتين. ومن نتائج هذه الدرلسة مق الاستنتاج بلن عقار 5-FU بالجرع المستخدة في هذ ولهية الدرلسة ارتبط مع حدوث افت نسجية مرضية في الرئة والخصية والمثانة البولية للفئران.
\end{abstract}




\section{INTRODUCTION}

5-Fluorouracil (5-FU) is considered one of the most effective agents against metastatic carcinomas of the gastrointestinal tract, mammary gland, ovary, and head and neck (Shibayama et al., 2011 ; Lamberti et al., 2012). It is an antimetabolite that acts during the S phase of the cell cycle and is activated by thymidine phosphorylase into fluorodeoxyuridylate (5-fluoro2, deoxyuridine, 5 -monophosphate 5 -FdUMP) that inhibits thymidylate synthase, thus preventing DNA synthesis, that leads to imbalanced cell growth and ultimately cell death (Abd-Ellah, 2012). 5-FU is also converted to 5-fluorouridine monophosphate (5-FUMP) and can be incorporated into RNA and thus leads to a defect in RNA processing and function (Abd - Ellah, 2012). The commonly reported clinical side-effects of 5-FU include mucositis, myelosuppression, diarrhea, vomiting, cardiotoxicity and pancreatic injury (Lamberti et al., 2012). Hepatotoxicity and general organ toxicity of 5-FU have been studied previously (Sundaram and Sangaval, 2009 ; Ali, 2012). However, there is very limited information on the histopathological effects of 5-FU toxicity on the histology of various internal organs. Therefore, this study was undertaken to investigate the histological changes that occur following the administration of 5-FU in variable doses and dose schedules to mice.

\section{MATERIALS AND METHODS}

One hundred and eight Swiss male mice, 3-4 months old and weighying 28-30 gm each were used. They were apparently healthy and reared in plastic cages in a small room with convenient temperature, illumination, and ventilation. The mice were divided into 9 equal groups of 12 mice each. The first three groups served as control, one of them was given one $\mathrm{ml}$ of physiological saline solution intraperitoneally (i .p.) once during the first day of the experiment, the second was given the same dose of physiological saline solution on the first and second days of the experiment and the third one was given the same dose of physiological saline solution on the first, second and third days of the experiment. The first experimental group of mice was given 5 -FU in a dose of $25 \mathrm{mg} / \mathrm{kg} \mathrm{b}$. w. on the first day of the experiment. Mice of the second experimental group were given the same dose of 5-FU on each of days one and two. Mice of the third group were given the same daily dose of 5-FU on each of days one, two, and three. Two weeks later, half of the control and experimental mice were euthanized using ether while the second half of the control and experimental mice were euthanized at four weeks following drug administration. Postmortem examination of the mice was done and tissue specimens were collected from the lungs, testes, and urinary bladder and fixed in $10 \%$ formalin for 48 hours. Following fixation, the specimens were washed, dehydrated, cleared in xylol, embedded in paraffin wax, sectioned at 5-6 $\mu \mathrm{m}$ thickness and stained with hematoxylin and eosin $(\mathrm{H} \& \mathrm{E})$, periodic acid-Schiff (PAS), and mercuric bromophenol stains (Kiernan, 2000). The stained slides were then examined under a light microscope and the lesions were photographed using a digital camera.

\section{RESULTS}

Cross sections of the lung, testis, and urinary bladder of normal controls mice are presented in Figs. 1-4. In mice of the first experimental group that were given a single intraperitoneal dose of 5-FU (25 $\mathrm{mg} / \mathrm{kg}$. b. w.) and were euthanized after two weeks there was thickening of the interalveolar septa of the lung due to congestion, hemorrhages, and the infiltration of inflammatory mononuclear cells. Histological changes that were seen in other organs included mild vacuolar degeneration of the spermatocytes and spermatids in the testis, and hyperplasia of the transitional epithelium lining the urinary bladder. In mice that were euthanized after four weeks there were emphysema, infiltration of inflammatory mononuclear cells in the interalveolar septa, and congestion of blood vessels in the interalveolar tissue (Figs. 5 and 6). The testes showed edema of the interstitium, vacuolar degeneration of the spermatocytes, and lack of spermatozoa (Fig. 7). Hyperplasia of the transitional epithelium of the urinary bladder was seen (Fig. 8). In mice of the second group that were given two consecutive 
intraperitoneal doses of $5-\mathrm{FU}\left(25 \mathrm{mg} / \mathrm{kg}\right.$. b. w. each) on the $1^{\text {st }}$ and $2^{\text {nd }}$ days of the experiment and sacrificed after two weeks, the histopathological changes in the lungs were similar to those seen in mice of the first experimental group that were euthanatised at four weeks. Mice of the second group that were sacrificed after four weeks showed emphysema, hemorrhages in the interalveolar spaces, infiltration of mononuclear cells in the interalveolar septa, and hyperplasia of the bronchiolar lining epithelium (Figs. 9 and 10). In the testes there were congestion of blood vessels in the interstitium, vacuolar degeneration of the spermatocytes, and lack of spermatozoa (Fig. 11). The urinary bladder exhibited congestions and hemorrhages in the submucosa and papillary hyperplasia of the mucosa (Fig. 12). Mice of the third group that were given intraperitoneal dose of 5-FU ( $25 \mathrm{mg} / \mathrm{kg} . \mathrm{b} . \mathrm{w}$.$) daily on$ each of the $1^{\text {st }}, 2^{\text {nd }}$, and $3^{\text {rd }}$ days, and euthanatised after two weeks showed pulmonary emphysema and thickening of interalveolar septa due to edema, hemorrhages, and mild infiltration of mononuclear cells (Fig. 13). In the testis there was a vacuolar degeneration of the spermatocytes, congestion of blood vessels within the interstitium, and hyperplasia of the interstitial cells (Fig.14). The urinary bladder exhibited congestion of blood vessels within the submucosa and papillary hyperplasia of the lining transitional epithelium (Fig. 15). Mice of the third group euthanized after four weeks showed that there were emphysema, peribronchiolar lymphoid hyperplasia, thickening of the interalveolar septa with mononuclear cells and fibrosis of the submucosa of the urinary bladder (Fig. 16).

\section{DISCUSSION}

5-FU is a widely used chemotherapeutic agent for the treatment of human malignancies . However, the clinical usefulness of 5-FU has been precluded because of its cardiotoxic, hepatotoxic and nephrotoxic side effects (El-Sayyad et al., 2009). Light microscopic changes that were seen in the heart of rats following the administration of $20 \mathrm{mg} \mathrm{5-FU/kg/day} \mathrm{intraperitoneally} \mathrm{for} 5$ days included focal atrophy, vacuolar degeneration, coagulative necrosis as well as cytolysis of myocytes. Interstitial edema together with inflammatory cell infiltration in between the damaged myocardiocytes were also observed (Abd-Ellah, 2012). Lamberti et al., 2012 found that 5-FU induced a time- and dose-dependent growth inhibition in both H9c2 rat cardiocytes and HT - 29 human colon adenocarcinoma cells. Treatment with $400 \mu \mathrm{M} 5$ - FU induced apoptosis in 32\% of H9c2 cells and this effect was increased by the addition of levofolene (LF) to $5-\mathrm{FU}$ (38\% of apoptotic cells). They also reported that apoptosis induced by 5 - FU and LF in cardiocytes was paralleled by the activation of caspases 3,9 and 7 and the intracellular increase of $\mathrm{O}^{2-}$ levels. Ali, 2012 reported that the injection of $5-\mathrm{FU}(20 \mathrm{mg} / \mathrm{kg} . \mathrm{b}$. wt. intraperitoneally) in rats resulted in a deterioration of hepatic function as indicated by elevation in ALT, AST, $\alpha$ AFP, bilirubin and glucose and by a significant decrease in total proteins and albumin. In the same study (Ali, 2012) it was found that 5 - FU caused a significant kidney injury manifested biochemically by a significant increase in serum urea, creatinine, uric acid, cortisol and potassium and by a significant decrease in sodium and magnesium. Nakamura et al., 2003 demonstrated the occurrence of absorption of 5-FU on the kidney surface in rats and that kidney surface application of this drug in rats could constitute kidney - and site-selective delivery. Hirano and Hirano, 1999 demonstrated in rats that the exocrine pancreas might be injured by $5-\mathrm{FU}$, and that lysosomal enzymes seem to play an important role in the pathogenesis of the pancreatic injuries induced by 5 FU. 5-FU treatment has been found to cause significant changes in intestinal flora and mucin secretion in rats and may lead to chemotherapy - induced mucositis (Stringer et al., 2009). Abnormalities that were seen in the testes in this study were similar to those reported by Mao et al., 2009. However, the histopathological lesions that were seen in the lung and urinary bladder have not been previously reported. These lesions included thickening of the interalveolar septa due to congestion, hemorrhages, and the infiltration of inflammatory mononuclear cells, vacuolar degeneration of the spermatocytes and spermatids, and hyperplasia of the transitional epithelium lining the urinary bladder. When the dose of 
5-FU was given for two days and the mice were necropsied after four weeks, the same previous changes were seen but they were more severe with a complete absence of the spermatozoa. From the results of this study, it was concluded that 5-FU in the dose regime used, caused histopathological abnormalities in the lung, testis and the urinary bladder of mice.

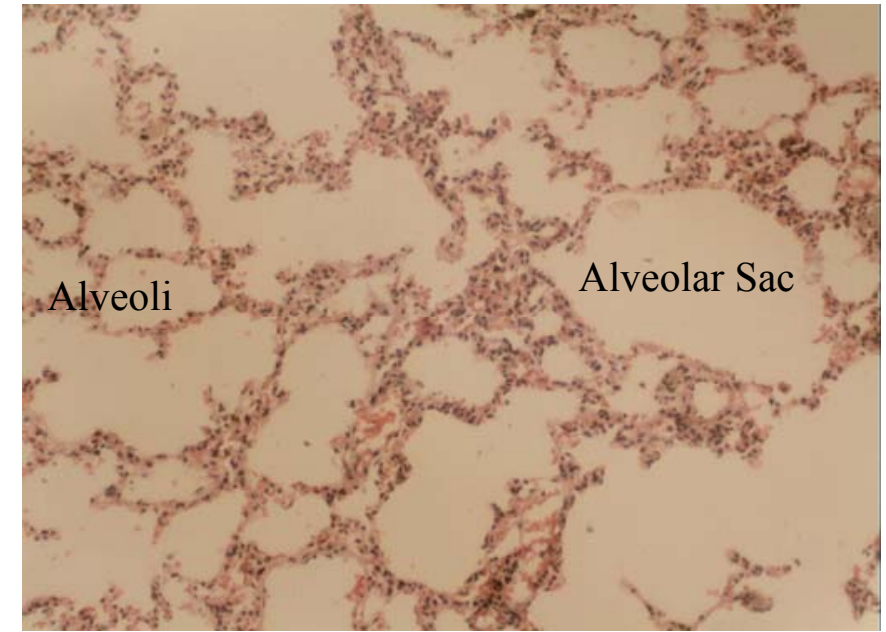

Fig. 1: Lung of a mouse from the normal control group. Note the sponge like appearance of the lung which is due to the abundance of alveoli and alveolar sac. H \& E. 100X.

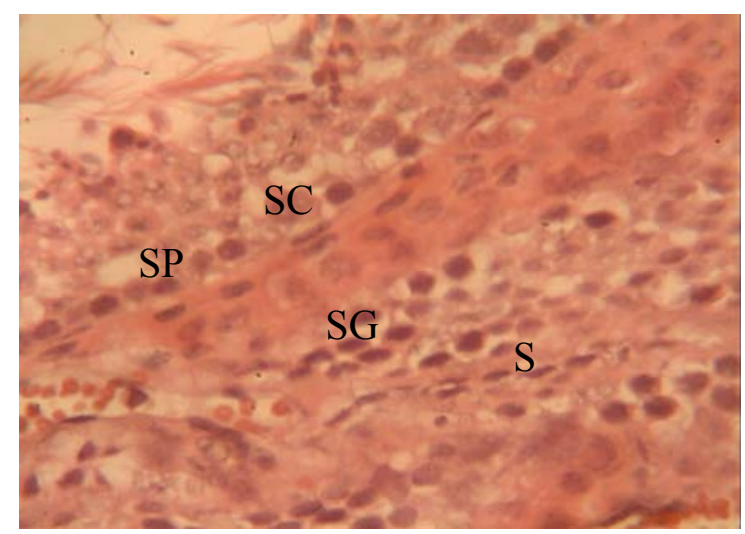

Fig. 3: High power magnification of the testis shown in Fig. 2 showing the Sertoli cells (SC), the spermatocytes (SP), the spermatogonia (SG), and the spermatids (S) . H \& E. 400X.

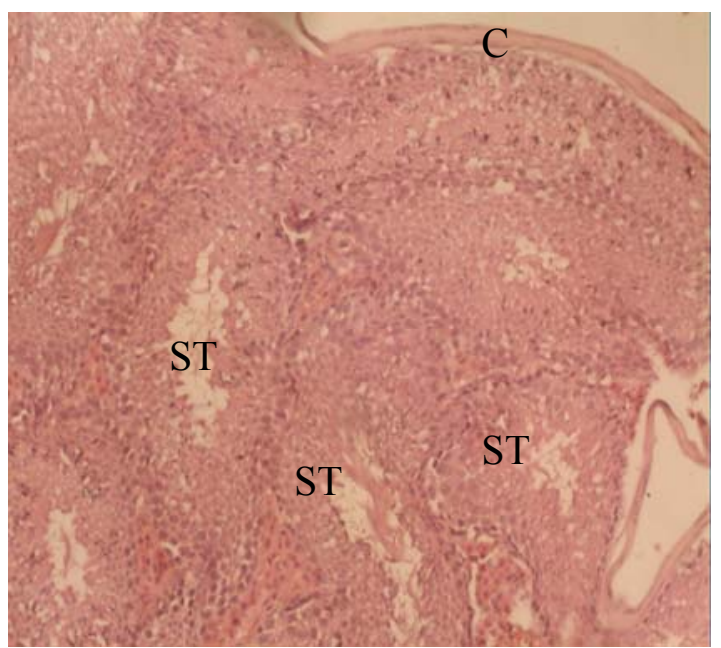

Fig. 2: Testis of a mouse from the normal control group showing the seminiferous tubules (ST) and the capsule (C). H \& E. 40X.

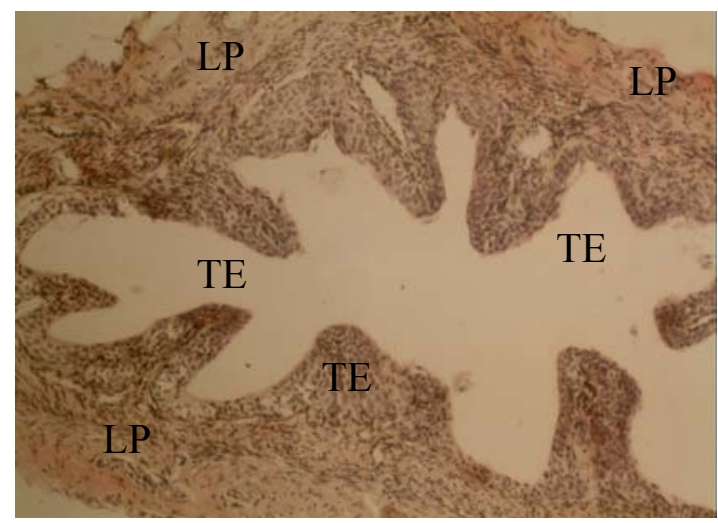

Fig. 4: Urinary bladder of a mouse from the normal control group showing the transitional epithelium (TE) and the connective tissue of the lamina propria (LP). H \& E. 100X. 


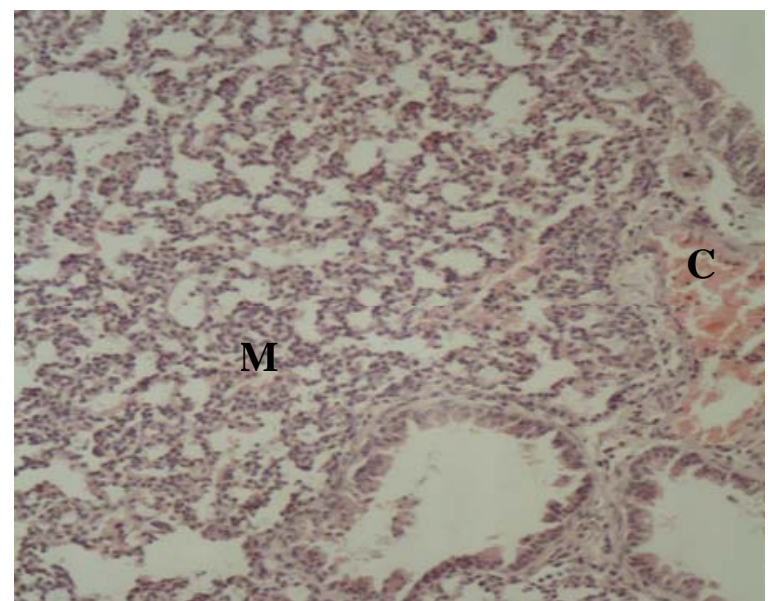

Fig. 5: Lung of a mouse of the first experimental group showing emphysema and thickening of the interalveolar septa due to congestion(C) and mononuclear cell infiltration(M). H \& E. 100X.

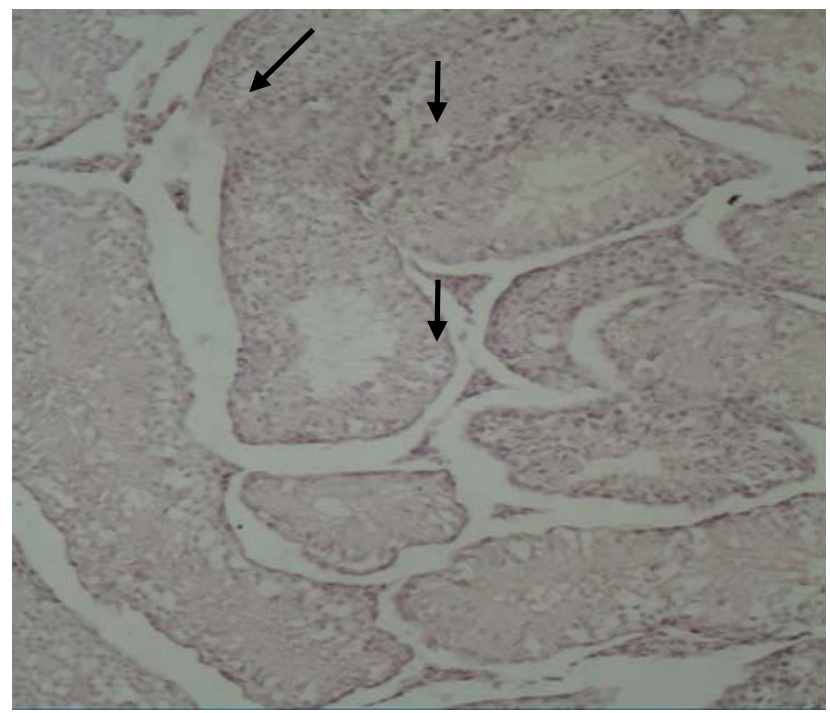

Fig. 7: Testis of a mouse of the first experimental group showing degeneration of spermatocytes (arrows). H \& E. 40X.

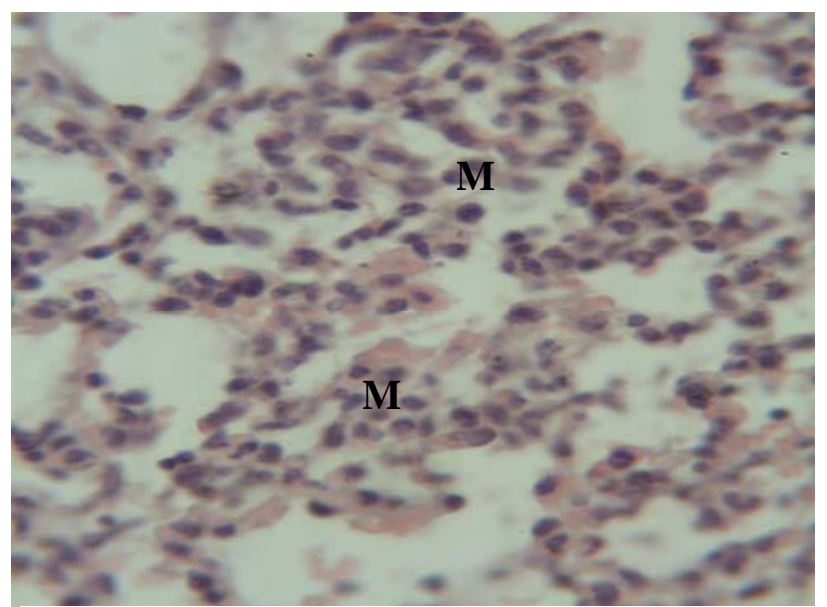

Fig. 6: A higher magnification of Fig. 5 showing thickening of the interalveolar septa due to congestion and mononuclear cell infiltration(M). H \& E. 400X.

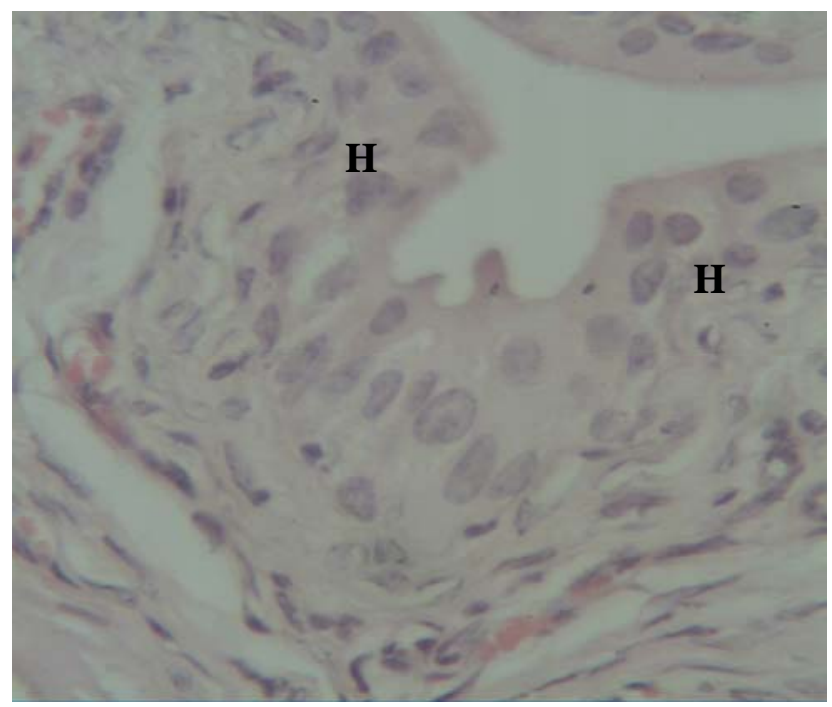

Fig. 8: Urinary bladder of the first experimental group showing hyperplasia of the transitional epithelium(H). H \& E. 400X. 


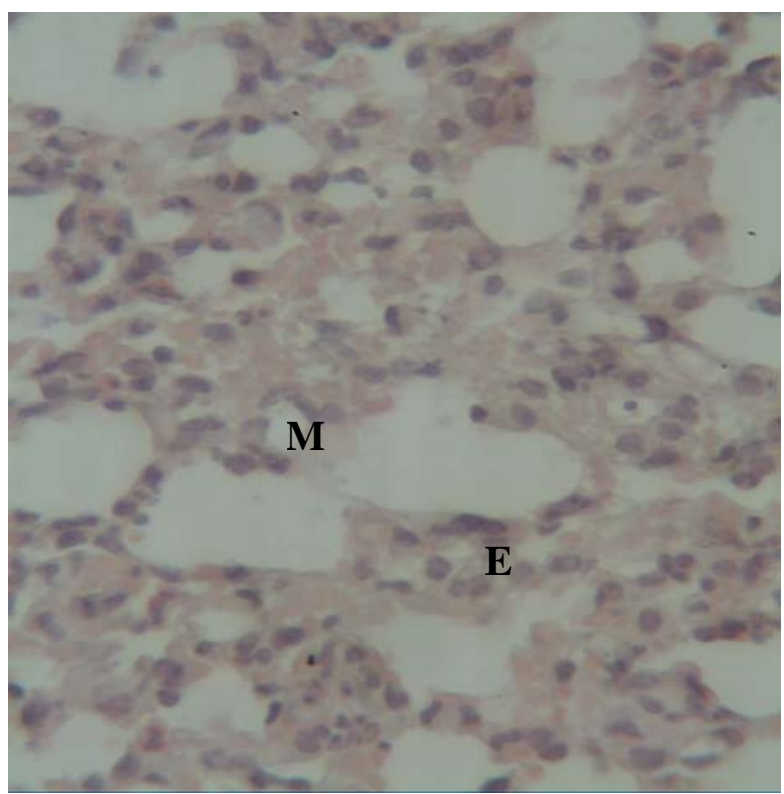

Fig. 9: Lung of a mouse of the second experimental group showing emphysema(E) and infiltration of mononuclear cells in the interstitium(M). H \& E. 400X.

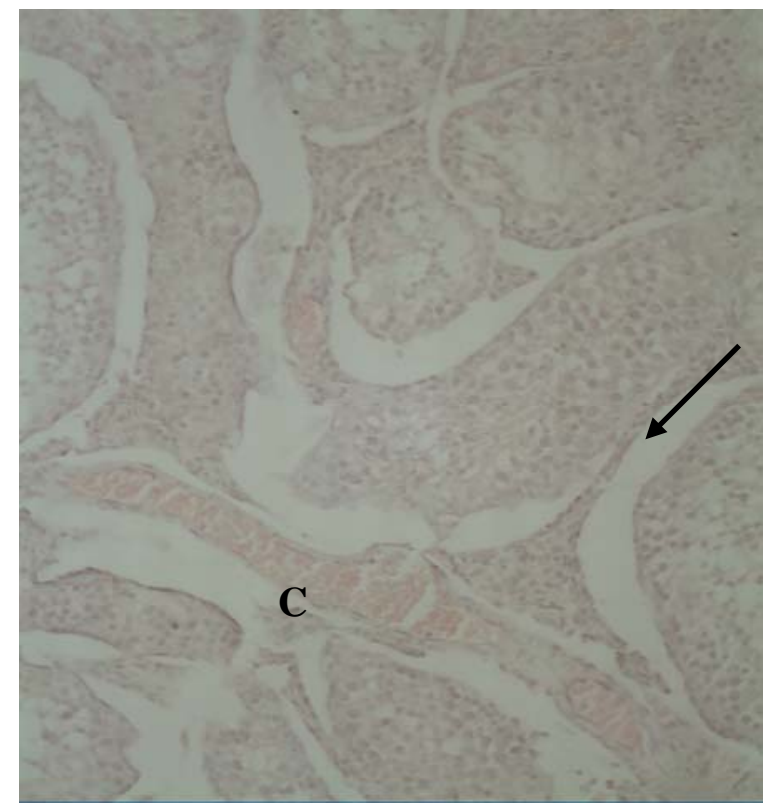

Fig. 11: Testis of the second experimental group showing congestion (C), vacuolar degeneration of spermatocytes (arrow) and lack of spermatozoa. H\&E. 40X.

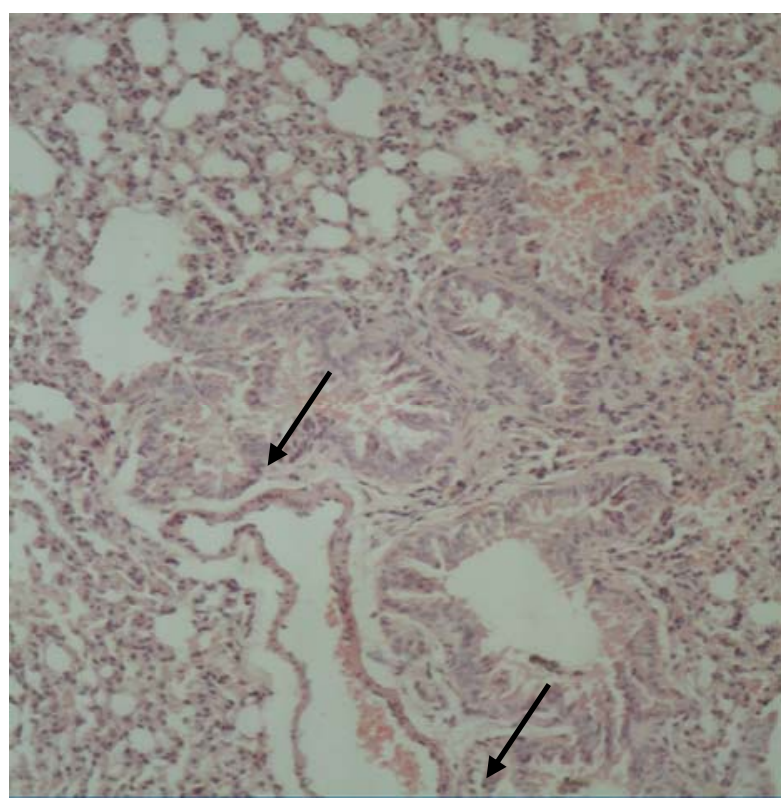

Fig. 10: Lung of a mouse of the second experimental group showing hyperplasia of the bronchiolar epithelium(arrow). H \& E. 100X.

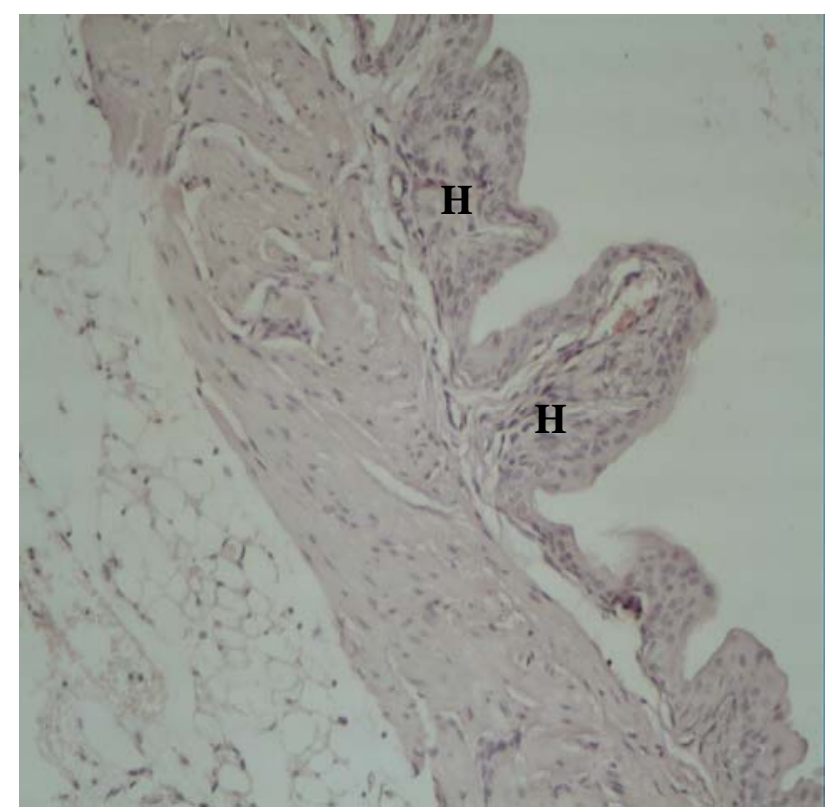

Fig. 12: Urinary badder of the second experimental group showing mild papillary hyperplasia of the mucosa(H). H \& E. 100X. 


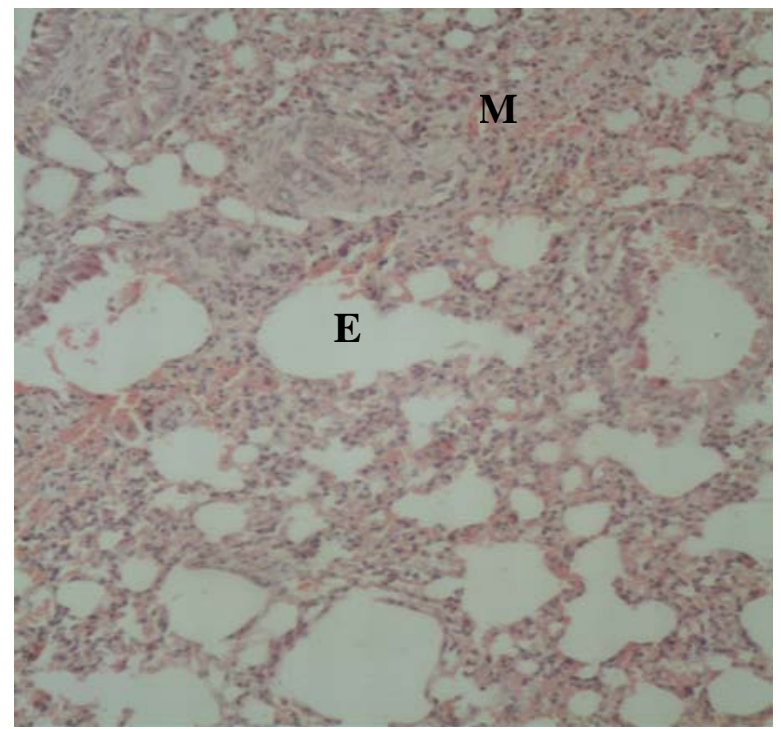

Fig. 13: Lung of a mouse of the third experimental group showing emphysema (E) and infiltration of mononuclear cells in the interstitium (M). H\& E. 100X.
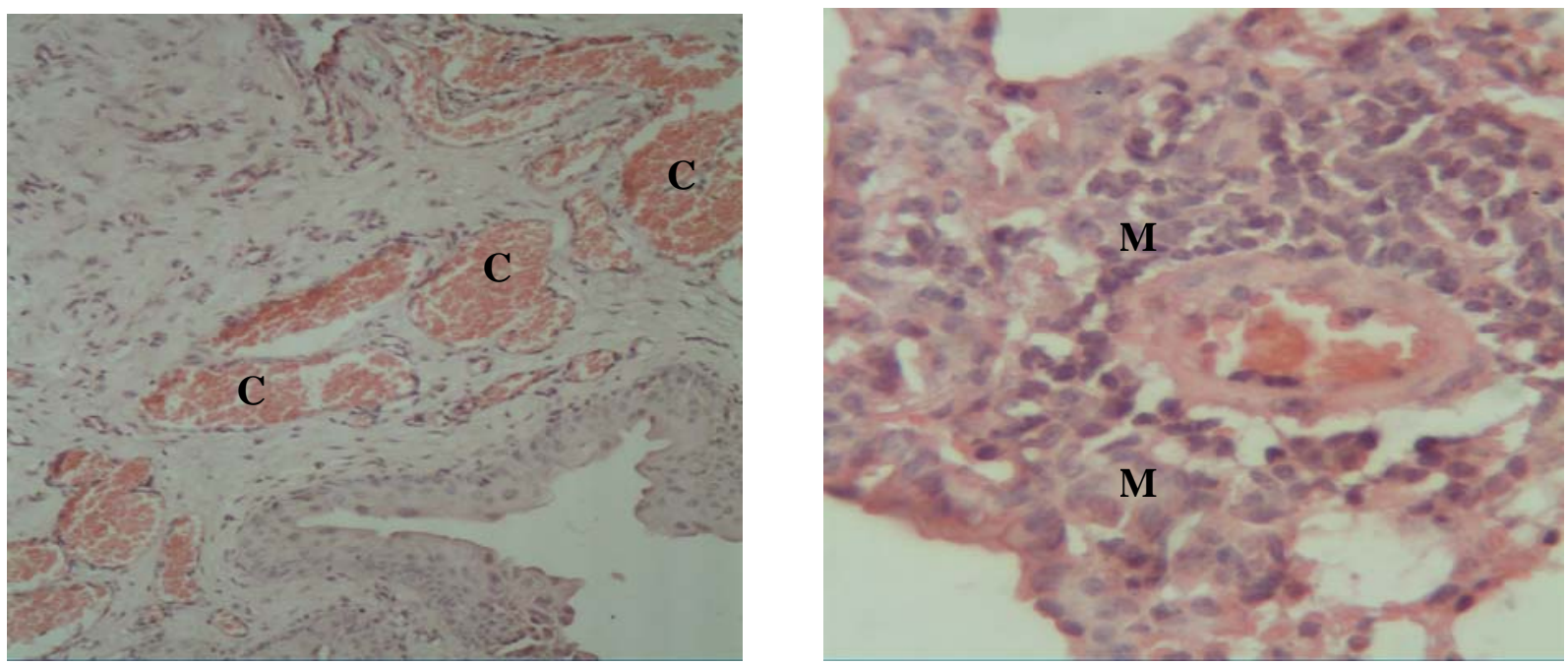

Fig. 15: Urinary bladder of the third experimental group showing congestion of blood vessels within the submucosa (C). H \& E. 100X.

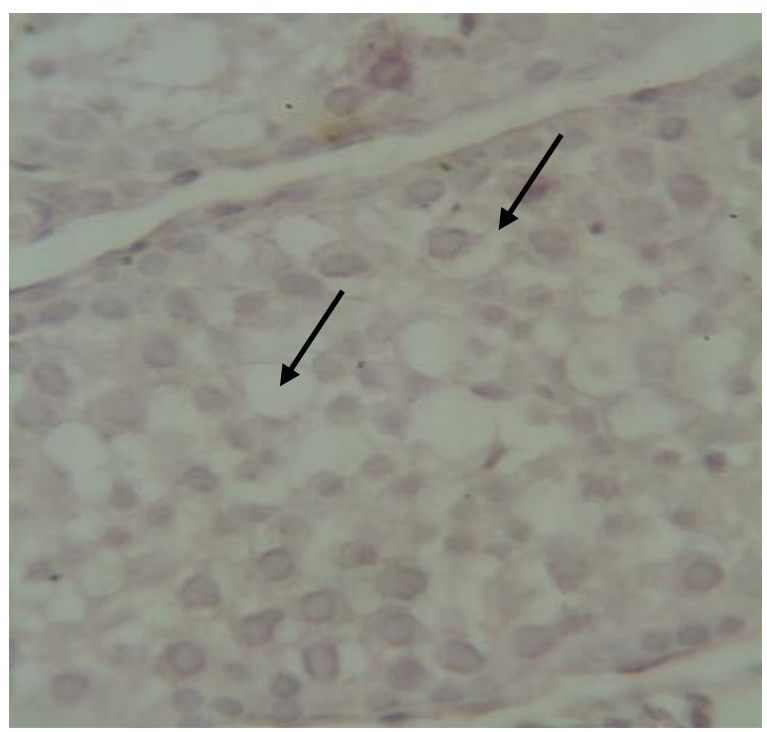

Fig. 14: Testis of the third experimental group showing vacuolar degeneration of spermatocytes (arrows). H \& E. 400X.
Fig. 16: Lung of a mouse of the third experimental group showing infiltration of mononuclear cells in the interstitium (M). $\mathrm{H} \& \mathrm{E}$. $400 X$. 


\section{REFERENCES}

Abd-Ellah, H.F. (2012). Ameliorative effect of captopril against 5-fluorouracil-induced cardiotoxicity in rats :a study with the light and electron microscopes. J. Appl. Sci. Res., 8(2), 863-872.

Ali, N.E.M. (2012). Protective effect of captopril against 5- fluorouracil-induced hepato and nephrotoxicity in male albino rats. J. Amer. Sci., 8(2), 680-685.

El-Sayyad, H.I.; Ismail, M.F.; Shalaby, F.M.; Abou-El-Magd, R.F.; Gaur, R.L.; Fernando, A.; Raj, M.H.; Ouhtit, A. (2009). Histopathological effects of cisplatin, deoxorubicin and 5- fluorouracil (5-FU) on the liver of male albino rats. Int. J. Biol. Sci., 5(5), 466-473.

Hirano, T.; Hirano, K. (1999). Effect of 5-fluorouracil (5-FU) on the isolated perfused rat pancreas. Int. J. Surg. Investig., 1(1),19-22.

Kiernan, J.A. (2000). "Histological and histochemical methods : theory and practice". 3rd edn., Oxford : Butterworth-Heinemann, UK.

Lamberti, M.; Porto, S.; Marra, M.; Zappavigna, S.; Grimaldi, A.; Feola, D.; Pesce, D.; Naviglio, S.; Spina, A.; Sannolo, N.; Caraglia, M. (2012). 5-Fluorouracil induces apoptosis in rat cardiocytes through intracellular oxidative stress. J. Exp. Clin. Cancer Res., 31(1), 60 (http://www.Jeccr.com/content/31/1/60).

Mao, W.W.; Mao, L.Y.; Jiang, F.; He, H.J. (2009). Early morphological changes in the mouse testis inducd by 5-fluorouracil. Zhonghua Nan Ke Xue, 15(12),1064-1067.

Nakamura, J.; Horimoto, T.; Hirayama, R.; Mukai, T.; Nakashima, M.; Sasaki, H.; Nishida, K. (2003). Further studies on the kidney-and site-selective delivery of 5-fluorouracil following kidney surface application in rats. Biol. Pharm. Bull., 26(12), 1761-1764.

Shibayama, Y.; Iwashita, Y.; Yoshikawa, Y.; Kondo, T.; Ikeda, R.; Takeda, Y.; Osada, T.; Sugawara, M.; Yamada, K.; Iseki, K. (2011). Effect of 5-fluorouracil treatment on SN-38 absorption from intestine in rats. Biol. Pharm. Bull., 34(9),1418-1425.

Stringer, A.M.; Gibson, R.L.; Logan, R.M.; Bowen, J.M.; Yeoh, A.S.; Hamilton, J.; Keefe, D.M.K. (2009). Gastrointestinal microflora and mucins may play a critical role in the development of 5fluorouracil-induced gastrointestinal mucositis. Soc. Exp. Biol. Med., DOI:10:3181/0810-RM301,1535-3702/09/2344-0430.

Sundaram, M.K.; Sangaval, R. (2009). Tissue processing effects of doxorubicin and 5-fluorouracil (5FU) on the hepatocyte region of albino rats. Advanced Biotech., December 2009, 23-25. 